\title{
The analysis of factors influencing tourists' choice of green hotels
}

\author{
Stefan Zdravković ${ }^{*}$, Jelena Peković ${ }^{1}$ \\ ${ }^{1}$ PhD student, University of Kragujevac, Faculty of Economics, Kragujevac, Serbia
}

\begin{abstract}
In addition to achieving economic goals, tourism companies must take care of social goals and the impact of their business activities on the environment. Social responsibility and economic profit are not contradictory, but rather complementary. Many companies implement Environmental Management System (EMS) in their business operations. Nowadays, Corporate Social Res ponsibility (CSR) is more and more represented in touris mand hotel industry. An increasing number of tourists are showing concern for the environment and they are staying in green hotels during their travels. The survey was conducted to determine whether the tourist's intention to stay at the green hotel is affected the tourists' care for the environment and the perceived value of the green hotel offers. Statistical analysis was performed on a sample of 155 respondents from the territory of the Republic of Serbia. The results of empirical research have shown that these variables have a positive impact on the choice of green hotels, so the study offers important practical implications for tourism and hospitality companies.
\end{abstract}

Keywords: corporate social responsibility, EMS, green hotels, perceived value of the offer, environmental care of touris ts

JEL classification: Q50, Q51, Z32

\section{Analiza faktora koji utiču na izbor zelenog hotela od strane turista}

Sažetak: Turis tička preduzeća pored ostvarenja ekonoms kih ciljeva moraju voditi računa o društvenim ciljevima i uticaju svojih poslovnih aktivnosti na životnu sredinu. Društvena odgovornost i ekonomski profit nisu u suprotnosti, već su komplementarni. Mnoge kompanije u s vompos lovanju implementiraju sis temzaštite životne s redine (Environmental Management System-EMS). Društveno odgovorno poslovanje je danas s ve viš e zas tupljeno u turizmu i hotelijerstvu, a sve veći broj turis ta pokazuje brigu o zaštiti životne sredine i prilikom svojih putovanja odseda u ,zelenim hotelima". Is traživanje je sprovedeno sa ciljem da se utvrdi da li varijable briga turista o zaštiti životne sredine i percipirana vrednost ponude ,zelenog hotela” utiču na nameru turista da odsednu u ,zelenom hotelu”. Statistička analiza je rađena na uzorku od 155 is pitanika sa teritorije Republike Srbije. Rezultati empirijskog istraživanja su pokazali da navedene varijable imaju pozitivan uticaj na izbor ,zelenih hotela", tako da studija nudi važne praktične implikacije za pružaoce usluga u oblasti turizma i hotelijers tva.

Ključne reči: društveno odgovorno poslovanje, EMS, ,zeleni hoteli”, percipirana vrednost ponude, briga turista o zaštiti životne sredine

JEL klasifikacija: Q50, Q51, Z32

*szdravkovic034@yahoo.com 


\section{Introduction}

Touris mis the industry with the greatest potential for growth. Touris ts increase the number of their trips over the years (Pejic Bach et al., 2014). Increasing efforts are being made to promote the socially responsible behavior of tourism companies (Lebe \& Milfelner, 2006). Corporate Social Responsibility (CSR) involves management that takes into account both economic and social goals (Ghoul et al., 2011). The primary business motive of any company is profit, but in recent years a large number of companies have paid attention to environmental protection and it involves the use of higher quality technology, optimal use of resources, reduction of emissions of gases and the like.

ISO 14000 is an international standard for environmental protection. It assists companies in the process of setting up an Environmental ManagementSystem(EMS). EMS is increasingly present in the hospitality industry and it enables organizations to control the impact of their business activities on the natural environment (Chan, 2008). Environmental protection is crucial and does not imply the suppression of touris m simply because there is a negative impact on the natural environment. Instead, it implies managing tourismin such a way that it does not adversely affect the nature and culture of the host country (Miththapala et al., 2013).

Cashman et al. (2012) claim that "human activities associated with economic and social development havealtered the composition of the globalatmo sphere through the emission of greenhouse gasses" (p. 17). Furthermore, small is land countries, which represent the most attractive tourist destinations, are most sensitive to the effects of climate change and the influence they have on the natural environment. Nowadays, increasing numbers of tourists show concern for the environment and, when traveling, stay in green hotels, which seek to reduce the environmental impact of certain activities (Cheng \& Wu, 2014). Statistics show that an increasing number of tourists are aware of the efforts being made by tourism and hos pitality companies to improve their environmental performance and it is projected that tourists will increasingly choose such hotels during their travels (Miththapala et al., 2013).

The subject of this research is environmental analysis, as well as tourists' impressions of green hotels and their des ire to stay there when traveling. The main objective of the research is to determine whether and to what extent the variables tourists' care for the environment and the perceived value of the green hotels offers affect the intention of touris ts to choose green hotels for their stay when traveling.

When it comes to the methodology used, the survey method was employed to collect data. Data analysis was performed using SPSS statistical software. Statistical analysis used descriptive statis tics (arithmetic mean and standard deviation), reliability analys is to assess internal consistency of model findings and validity, correlation and multiple regression analysis to confirm or reject research hypotheses.

The work cons is ts of five parts. Following the introduction, the literature review analyzes tourists' care for the environment, the perceived value of the green hoteloffers and tourists' preferences for staying there during their travels. Within this section, research hypotheses are formulated and a conceptual model is presented. The third part presents the research methodology and sample structure. The fourth part contains the results of the research, while the fifth part outlines the main contributions of the research, theoretical and managerial implications, limitations and directions of future res earch.

\section{Literature review}

EMS system has become increasingly known worldwide in the hotel industry lately. The sys temprovides an opportunity for companies to reduce the negative impact of their business 
activities on nature (Chan, 2009). Steger (2000) describe EMS as a "transparent, systematic process known corporate-wide, with the purpose of prescribing and implementing environmental goals, policies and res ponsibilities, as well as regular auditing of its elements" (p. 24).

Stipanuk (1996) states that almost all hotels are familiar with the EMS system and have implemented it in their operations in order to reduce the negative influence of their business activities on the nature. The implementation of the EMS systemenables the company to do socially responsible business, but, on the other hand, it can also gain a certain financial benefit. The international standard ISO 14000 provides guidelines for the evolution of the EMS system, which allows reducing business costs, process optimization and the like, which ultimately affects the profit of the organization. Chan and Ho (2006) state that organizations need knowled ge, experience and expertise as well as significant financial resources to build an EMS sys tem. Furthermore, it is neces sary to animate tourists in marketing campaigns to contribute to environmental programs and pay an additional amount to support environmental policy.

The touris mindustry is working hard to offer consumers the opportunity to help protect the environment. Many travelagencies offer travelers the opportunity to pay a certain fee when booking a trip, which allows for a reduction in environmental pollution (Dhanda, 2014). Nowadays, green marketing is experiencing a significant increase in popularity. Green marketing activities include modifications in the production process and saving of resources, promotion of products with environmental characteristics, eco-friendly packaging and the like.

Nowadays, socially responsible actions are expected not only fromlarge hotels but also from small and medium-sized hotels (Kasim, 2015). All organizations need to make the effort and find creative and innovative solutions to reduce the negative influence of their business activities on the nature. CSR has a positive impact on the image of organizations and thanks to the rapid development of the Internet and communication, as well as the increasing importance of social networks, consumers are easily informed about the environmental programs used by hotels (Chan \& Hsu, 2016). In addition to having a positive impact on the image of organizations, environmental policy also contributes to the growth of a loyal cus tomer base, es pecially those who care about the natural environment (Gürlek et al., 2017). Tourists who take care of the environment stay in green hotels when traveling, as they implement environmental policies in a way that minimizes the negativeeffects on the natural environment (Gustin \& Weaver, 1996).

From a marketing pers pective, in order for a consumer to achieve a degree of satisfaction, it is neces sary for the product or service to be of a high degree of quality and to meet the needs of consumers with their performance (Hwang \& Seo, 2016). Similarly, green hotels are organizations that implement environmental programs to reduce the negative influence of their business activities on the nature. Environmental activities include solar heating, thermal systems, recycling for all waste materials, eco-friendly equipment, energy-saving lamps, healthy food and the like. Conservation of natural resources creates desirable values for tourists who are about the environment. Environmental protection or ecological value involves the care and effort of an individual to preserve the natural environment (Thompson $\&$ Barton, 1994). Individuals who advocate the implementation of environmental programs seek to collaborate with organizations that implement such programs, because they believe that nature is valuable in itself and that natural resources must be conserved for a better quality of life. In their research, Teng et al. (2018) found that tourists' concern for the environment had a positive impact on tourist's decision to choose a green hotel when traveling. Cvijanović et al. (2018) found that the implementation of environmental standards 
in the hotel industry has a positive impact on the satisfaction and loyalty of tourists, as well as their intention to recommend their friends through social networks to use the services of green hotels. The same authors state that in Serbia a small number of hotels apply environmental standards and that their application would be a factor of differentiation and gaining a competitive advantage. From the abovementioned, it can be concluded that the concept of green hotels has a development perspective in Serbia and that customers do pay attention to environmental protection. Based on the above, the first research hy pothesis in the paper can be formulated:

H1: Tourists' care for the environment has a positive statistically significant impact on the choice of a green hotel to stay in when traveling.

When tourists choose a hotel, they consider the conditions and the whole offer. The perceived value of a green hotel offer is the choice of hotels that applies socially responsible behavior, the general impression of those hotels, the experiences of acquaintances and the like (Tzschentke et al., 2004). If staying in a green hotel has left a favorable impression on tourists, and gave them a sense of satisfaction and affordable accommodation, they will probably choose the same hotel for their next trip (Teng et al., 2018). Many studies of touris mand hospitality have shown that the perceived value of the offer has a significant impact on tourists' intention to choose a particular hotel when traveling (Chen \& Chen, 2010; Ryu et al., 2008). Similar is the situation with the perceived value of green hotels and their choice of touris ts when traveling. Based on the above, a second research hy pothesis can be formulated in the paper:

H2: The perceived value of a green hotel offers has a positive statistically significant impact on the tourists' choice of a green hotel to stay in when traveling.

The paper starts with the conceptual model presented in Figure 1, which monitors the impact of tourists' care for the environment and the perceived value of a green hotel offers on tourists' intention to choose a green hotel for their stay.

Figure 1: Conceptual model

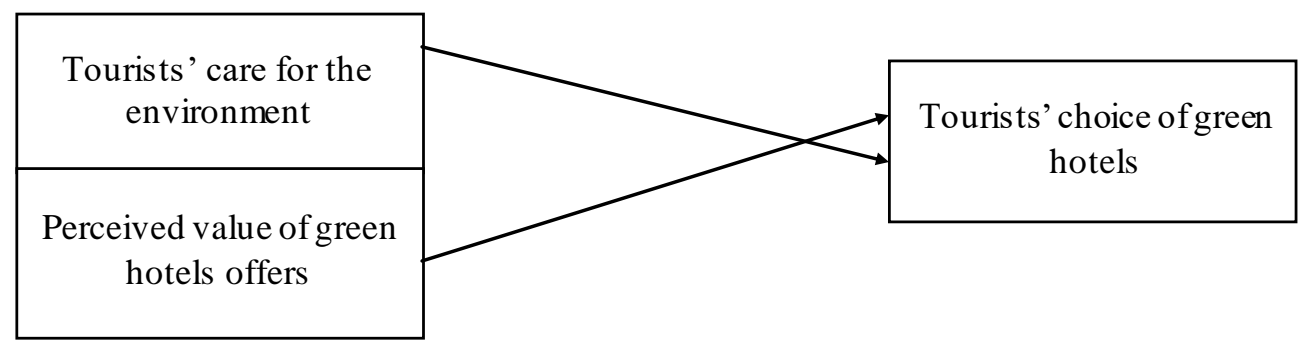

Source: Author's research

\section{Research methodology}

The survey was conducted on the territory of the Republic of Serbia. The condition for respondents to participate in the survey was that they were familiar with the concept of green hotels. A total of 180 questionnaires were distributed. Out of the total number, 155 respondents were familiar with the concept of green hotels and 25 were not, which excluded them from the survey. Based on the abovementioned, the sample includes 155 respondents. The survey was conducted in written and electronic form, using the questionnaire method. Respondents evaluated statements by a seven-point Likert scale. The statements were taken from relevant works in the literature which dealt with the is sue of socially responsible 
businessin touris m. An overview of the statements is given in Table 1. Statistical software IBM SPSS Statistics Version 23 (Statis tical Package for Social Sciences) was used for data analysis. Statistical analysis used descriptive statistics (arithmetic mean and standard deviation), reliability analy sis to assess internal consistency of model findings and validity, correlation and multiple regression analysis to test research hypotheses.

Table 1: Research variables based on the grouping of the statements used

\begin{tabular}{|c|c|c|}
\hline Variables & $\begin{array}{l}\text { Statements } \\
\end{array}$ & Source \\
\hline $\begin{array}{l}\text { Tourists' care } \\
\text { for the } \\
\text { environment }\end{array}$ & $\begin{array}{l}\text { 1. It is sad to seethe destroyed natural } \\
\text { environment. } \\
\text { 2. Nature is precious in its elf. } \\
\text { 3. Conservation of natural res ources is } \\
\text { important for good health and better quality } \\
\text { of life. }\end{array}$ & \multirow{2}{*}{$\begin{array}{c}\text { Adapted to: } \\
\text { Teng et al. (2018) }\end{array}$} \\
\hline $\begin{array}{c}\text { Perceived } \\
\text { value of green } \\
\text { hotels offers }\end{array}$ & $\begin{array}{l}\text { 4. My friends were pleased with their stay at } \\
\text { a green hotel. } \\
\text { 5. Staying at a green hotel gives people a } \\
\text { sense of satisfaction. } \\
\text { 6. Green hotels offer affordable } \\
\text { accommodation rates. }\end{array}$ & \\
\hline $\begin{array}{l}\text { Tourists' } \\
\text { choice of green } \\
\text { hotels }\end{array}$ & $\begin{array}{l}\text { 7. I will stay at a green hotel when the first } \\
\text { opportunity arises. } \\
\text { 8. I want to stay at a hotel that cares about } \\
\text { the environment. } \\
\text { 9. I think a green hotel is a good choice. }\end{array}$ & $\begin{array}{c}\text { Adapted to: } \\
\text { Tilikidou \& } \\
\text { Delistavrou (2015) }\end{array}$ \\
\hline
\end{tabular}

Source: Author's research

An overview of the demographic structure of the respondents is given in Table 2. Segmentation was performed based on the criteria of gender, age and education.

Table 2: Demographic structure of respondents

\begin{tabular}{|l|l|c|c|}
\hline \multirow{4}{*}{ Gender } & Number of & $\begin{array}{c}\text { Percent of } \\
\text { respondents }\end{array}$ & 54.8 \\
\hline \multirow{4}{*}{ Age } & Females & 85 & 45.2 \\
\cline { 2 - 4 } & Male & 70 & $\mathbf{1 0 0 \%}$ \\
\cline { 2 - 4 } & Total & $\mathbf{1 5 5}$ & 12.9 \\
\hline \multirow{5}{*}{ Education } & Up to17 years of age & 20 & 40.0 \\
\cline { 2 - 4 } & $18-30$ years of age & 62 & 34.8 \\
\cline { 2 - 4 } & 31-50 years of age & 54 & 12.3 \\
\cline { 2 - 4 } & 51 years and older & 19 & $\mathbf{1 0 0 \%}$ \\
\cline { 2 - 4 } & Total & $\mathbf{1 5 5}$ & 5.8 \\
\hline & Primary education & 9 & 47.1 \\
\cline { 2 - 4 } & Secondary education & 73 & 7.7 \\
\cline { 2 - 4 } & College education & 12 & 39.4 \\
\cline { 2 - 4 } & University & 61 & $\mathbf{1 0 0} \%$ \\
\cline { 2 - 4 } & Total & $\mathbf{1 5 5}$ & \\
\hline
\end{tabular}

Source: Author's research 
In the sample of 155 respondents, there are 85 women and 70 men. The majority of respondents were between the age of 18 and 30, 62 in total(40\%). In terms of education, the highest number of res pondents have secondary education $73(47.1 \%)$.

\section{Research results}

The study first used a descriptive statistical analysis. Table 3 shows the results.

Table 3: Results of descriptive statistical analys is

\begin{tabular}{|l|c|c|}
\hline \multicolumn{1}{|c|}{ Statements } & M & SD \\
\hline 1. It is sad to see the destroyed natural environment. & 5.48 & 1.97 \\
\hline 2. Nature is precious in itself. & $\mathbf{5 . 5 7}$ & 1.91 \\
\hline $\begin{array}{l}\text { 3. Conservation of natural res ources is important for good health and } \\
\text { better quality of life. }\end{array}$ & 5.08 & $\mathbf{1 . 2 6}$ \\
\hline 4. My friends were pleased with their stay at the green hotel. & $\mathbf{4 . 0 4}$ & 2.00 \\
\hline 5. Staying at a green hotel gives people a sense of satis faction. & 4.50 & 1.94 \\
\hline 6. Green hotels offer affordable accommodation rates. & 4.87 & $\mathbf{2 . 0 8}$ \\
\hline 7. I will stay at a green hotel when the first opportunity arises. & 4.81 & 1.80 \\
\hline 8. I want to stay at a hotel that cares about the environment. & 5.01 & 2.04 \\
\hline 9. I think a green hotel is a good choice. & 4.25 & 1.75 \\
\hline
\end{tabular}

Source: Author's research

The most positive attitudes were expressed by the respondents in the statement Nature is precious in itself(arithmetic mean 5.57). The most negative attitudes were expres sed by the respondents in the statement My friends were pleased with their stay at the green hotel (arithmetic mean 4.04). Respondents' attitudes are the most homogeneous based on the statement Conservation of natural resources is important for good health and better quality of life (the lowest standard deviation value is 1.26). The attitudes of the responden ts are the most heterogeneous in the statement Green hotel offers affordable accommodation rates (the highest standard deviation value 2.08).

In the second step, a reliability analy sis was performed to determine the internal consistency of the findings by which certain variables are measured. Reliability analys is is usually performed by considering the values of the Cronbach's alpha coefficient. For a given variable to have an adequate degree of reliability, it is necessary that the value of this coefficient be higher than 0.70 (Nunnally, 1978). Table 4 presents the results obtained.

Table 4: Reliability analy sis

\begin{tabular}{|c|c|}
\hline Variables & $\begin{array}{c}\text { Cronbach's } \\
\text { alpha }\end{array}$ \\
\hline Tourists' care for the environment & 0.75 \\
\hline Perceived value of green hotels offers & 0.82 \\
\hline Tourists' choice of green hotels & 0.80 \\
\hline
\end{tabular}

Source: Author's research

The results show that the value of the Cronbach's alpha coefficient is higher than 0.70 in the case of all the variables used, which confirms that the variables are measured by adequate mutually consis tent statements. A correlation analysis was us ed to determine whether there was a statis tically significant relationship between the variables. Table 5 shows the results. 
Table 5: Correlation matrix

\begin{tabular}{|c|c|c|c|}
\hline & $\begin{array}{c}\text { Touris ts' care for } \\
\text { the environment }\end{array}$ & $\begin{array}{c}\text { Perceived value of } \\
\text { green hotels offers }\end{array}$ & $\begin{array}{c}\text { Tourists' choice } \\
\text { of green hotels }\end{array}$ \\
\hline $\begin{array}{c}\text { Tourists' care for the } \\
\text { environment }\end{array}$ & 1 & $0.296^{* *}$ & $0.424^{* *}$ \\
\hline $\begin{array}{c}\text { Perceived value of } \\
\text { green hotels offers }\end{array}$ & $0.296^{* *}$ & 1 & $0.358^{* *}$ \\
\hline $\begin{array}{c}\text { Tourists' choice of } \\
\text { green hotels }\end{array}$ & $0.424^{* *}$ & $0.358^{* *}$ & 1 \\
\hline
\end{tabular}

Note: $* *$ Correlation coefficients are significant at the 0.01 level

Source: Author's research

Based on the results of the correlation analysis, it can be concluded that all values of Pearson's correlation coefficient are statistically significant. The highest degree of linear correlation is present between the variables of Tourists' care for the environment and Tourists' choice of green hotels (the highest coefficient value of 0.424). The lowest degree of linear correlation is present between the variables of Tourists' care for the environment and Perceived value of green hotels offers (the lowest coefficient value is 0.296).

The study applied multiple reg ression analy sis, which measured the impact of independent variables Tourists' care for the environment and Perceived value of green hotels offers on dependent variable Tourists' choice of green hotels. The results are shown in Table 6.

Table 6: Results of multiple regression analysis (dependent variable: Tourists' choice of green hotels)

\begin{tabular}{|c|c|c|c|c|}
\hline Variables & $\boldsymbol{\beta}$ & Sig & $\mathbf{t}$ & VIF \\
\hline $\begin{array}{c}\text { Tourists' care for } \\
\text { the environment }\end{array}$ & $0.348^{* *}$ & 0.000 & 4.698 & 1.092 \\
\hline $\begin{array}{c}\text { Perceived value of } \\
\text { green hotels offers }\end{array}$ & $0.255^{* *}$ & 0.001 & 3.448 & 1.096 \\
\hline
\end{tabular}

Note: $* *$ The coefficients are statis tically significant at the 0.01 level; $\mathrm{R}^{2}=0.356$

Source: Author's research

The coefficients of determination $\mathrm{R}^{2}$ is 0.356 , which means that $35.6 \%$ of the variability in the choice of green hotels by tourists is explained by this regress ion model. The data are suitable for conducting multiple regres sion analysis because the value of VIF coefficients in all pairs is less than 5, so there is no problem of multicollinearity (Field, 2000). The results show that the Tourists' care for the environment $(\beta=0.348$, Sig value $<0.01)$ and Perceived value of green hotels offers $(\beta=0.255$, Sig value $<0.01)$ have a statistically significant influence on the Tourists' choice ofgreen hotels. Based on the abovementioned, it can be concluded that both research hypotheses defined in the paper, $\mathrm{H} 1$ and $\mathrm{H} 2$, have been confirmed.

\section{Conclusion}

A number of authors have been res earching socially res ponsible tourismbusiness. This study examined the impact of variables Tourists' care for the environment and Perceived value of green hotels offers on the Tourists' choice of green hotels. The results show that both variables have a positive s tatistically significant effect on touris ts' intention to choose green hotels for stay when traveling, soboth research hypotheses are confirmed. Green marketing has become quite important and many organizations, including hotels, are trying to attract 
"green customers". The choice of a green hotel by touris ts has so far been addressed in a very small number of studies, which reflects the main contribution and originality of the paper. The theoretical contribution is reflected in the expansion of scientific knowledge about green hotels. Theresults show that tourists who take care of the environment choose green hotels for their stay when traveling. Previous research has come to similar results (Cvijanović et al., 2018; Teng et al., 2018), so these claims have been proven in this research as well. Moreover, the results of this research have shown that the perceived value of the green hotel offer has a positive effect on the choice of the green hotel by tourists and the previous research has yielded similar results (Chen \& Chen, 2010; Ryu et al., 2008). The findings of the study offer useful managerial implications. The results show that touris ts from the Republic of Serbia care about the protection of the environment and that they are familiar with the concept of green hotels, as well as that they show the intention to stay in hotels that implement certain environmental programs during the next trip. However, in Serbia the concept of green hotels has not yet been sufficiently developed. Hospitality service providers should pay attention and make an effort to implement environmental policies, in order to gain tourists' trust and ultimately increase profits. Cvijanović et al. (2018) als o point out that the strategy, which involves the implementation of environmental programs in the hotel industry can be the basis for gaining a competitive advantage. The green marketing trend is expected to continue to grow, so implementing eco-programs is a good way for tourismand hospitality service providers to achieve better business results. However, this study has some limitations. The sample size is small, and the age structure shows that mostly young respondents participated in the research. Future research should involve larger sample and include elder respondents. It is desirable to apply tests that show whether there is a difference in the respondents' views on environmental protection and the choice of a green hotel when traveling in terms of demographic characteristics. Moreover, it would be us eful to conduct research in other countries, as this would create an opportunity to compare the views of members of different nations on the imple mentation of environmental programs and the choice of green hotels by tourists.

\section{References}

1. Cashman, A., Cumberbatch, J., \& Moore, W. (2012). The effects of climate change on touris min small states: evidence from the Barbados case. Tourism Review, 67(3), 17-29. https://doi.org/10.1108/16605371211259803

2. Chan, E., \& Hsu, C. (2016). Environmental management research in hospitality. International Journal of Contemporary Hospitality Management, 28(5), 886-923. https ://doi.org/10.1108/IJCHM-02-2015-0076

3. Chan, E. S. W. (2008). Barriers to EMS in the hotel industry. International Journal of Hospitality Management, 27(2), 187-196. https ://doi.org/10.1016/j.ijhm.2007.07.011

4. Chan, W. (2009). Environmental measures for hotels' environmental management sys tems: ISO 14001. International Journal of Contemporary Hospitality Management, 21(5), 542-560. https://doi.org/10.1108/09596110910967791

5. Chan, W., \& Ho, K. (2006). Hotels' environmental management systems (ISO 14001): creative financing strategy. International Journal of Contemporary Hospitality Management, 18(4), 302-316. https ://doi.org/10.1108/09596110610665311

6. Chen, C. F., \& Chen, F. S. (2010). Experience quality, perceived value, satisfaction and behavioral intentions for heritage tourists. Tourism Management, 31(1), 29-35. https://doi.org/10.1016/j.tourman.2009.02.008

7. Cheng, T. M., \& Wu, H. C. (2014). How do environmental knowledge, environmental sensitivity, and place attachment affect environmentally responsible behavior? An 
integrated approach for sustainable Is land tourism. Journal of Sustainable Tourism, 23(4), 557-576. https://doi.org/10.1080/09669582.2014.965177

8. Cvijanović, D., Sekulić, D., \& Pavlović, D. (2018). Are green hotels suitable for the development of entrepreneurship in tourism? Ekonomika preduzeća, 66(7/8), 424-432. https://doi.org/10.5937/ekopre1808424c

9. Dhanda, K. (2014). The role of carbon offsets in achieving carbon neutrality: An exploratory study of hotels and resorts. International Journal of Contemporary Hospitality Management, 26(8), 1179-1199. https://doi.org/10.1108/IJCHM-03-20130115

10. Field, A. (2000). Discovering statistics using SPSS for Windows. Thous and Oaks: Sage Publication.

11. Ghoul, S. E., Guedhami, O., Kwok, C. C. Y., \& Mishra, D. R. (2011). Does corporate social responsibility affect the cost of capital. Journal of Banking \& Finance, 35(9), 2388-2406. https://doi.org/10.1016/j.jbankfin.2011.02.007

12. Gustin, M. E., \& Weaver, P. A. (1996). Are hotels prepared for the environmental consumer? Journal of Hospitality and Tourism Research, 20(2), 1-14. https://doi.org/10.1177\%2F109634809602000201

13. Gürlek, M., Düzgün, E., \& Meydan Uygur, S. (2017). How does corporate social responsibility create customer loyalty? The role of corporate image. Social Responsibility Journal, 13(3), 409-427. https://doi.org/10.1108/SRJ-10-2016-0177

14. Hwang, J., \& Seo, S. (2016). A critical review of research on customer experience management: theoretical, methodological and cultural perspectives. International Journal of Contemporary Hospitality Management, 28(10), 2218-2246. https://doi.org/10.1108/IJCHM-04-2015-0192

15. Kasim, A. (2015). Environmental management system (EMS): Postulating the value of its adoption to organizational learning in hotels. International Journal of Contemporary Hospitality Management, 27(6), 1233-1253. https://doi.org/10.1108/IJCHM-01-20140045

16. Lebe, S. S., \& Milfelner, B. (2006). Innovative organisation approach to sustainable tourism development in rural areas. Kybernetes, 35(7/8), 1136-1146. https://doi.org/10.1108/03684920610675139

17. Miththapala, S., (Chandi) Jayawardena, C., \& Mudadeniya, D. (2013). Responding to trends: Environmentally-friendly sustainable operations (ESO) of Sri Lankan hotels. Worldwide Hospitality and Tourism Themes, 5(5), 442-455. https://doi.org/10.1108/WHATT-05-2013-0027

18. Nunnally, J. C. (1978). Introduction to Psychological Measurement. New York: McGraw-Hill.

19. Pejic Bach, M., Zoroja, J., \& Merkac-Skok, M. (2014). Social responsibility in tourism: systemarchetypes approach. Kybernetes, 43(3/4), 587-600. https://doi.org/10.1108/K09-2013-0195

20. Ryu, K., Han, H., \& Kim, T. H. (2008). The relationships among overall quick-casual restaurant image, perceived value, customer satisfaction, and behavioral intentions. International Journal of Hospitality Management, 27(3), 459-469. https ://doi.org/10.1016/j.jhm.2007.11.001

21. Steger,U.(2000). Environmental management systems: Empirical evidence and further perspectives. European Management Journal, 18(1), 23-37. https ://doi.org/10.1016/S0263-2373(99)00066-3

22. Stipanuk, D. M. (1996). The US lodging industry and the environment - a historical view. Cornell Hotel and Restaurant Administration Quarterly, 37(5), 39-45. https://doi.org/10.1177\%2F001088049603700522 
23. Teng, C., Lu, A., \& Huang, T. (2018). Drivers of consumers' behavioral intention toward green hotels. International Journal of Contemporary Hospitality Management, 30(2), 1134-1151. https://doi.org/10.1108/IJCHM-04-2017-0203

24. Thompson, Z. G., \& Barton, M. A. (1994). Ecocentric and anthropocentric attitudes toward the environment. Journal of Environmental Psychology, 14(2), 149-157. https://doi.org/10.1016/S0272-4944(05)80168-9

25. Tilikidou, I., \& Delistavrou, A. (2015). Preferring green and rejecting “unethical” hotels. EuroMed Journal of Business, 10(3), 285-296. https://doi.org/10.1108/EMJB-09-20140026

26. Tzschentke, N., Kirk, D., \& Lynch, P. A. (2004). Reas ons for going green in serviced accommodation establishments. International Journal of Contemporary Hospitality Management, 16(2),116-124. https://doi.org/10.1108/09596110410520007 